\title{
Jayanta Mahapatra's Poetry: A Celebration of Identity
}

\author{
Aditi Jana \\ [Ex-student of Burdwan University, India]
}

\begin{abstract}
Jayanta Mahapatra is one of the leading postcolonial Indian English poets. He has written as many as 16 volumes of poems. In his works he tries earnestly to explore the rich heritage, culture, myths, riruals, folktales, beliefs and customs of Orissa. He is not confined to his birthplace. He embraces Indian ethos in its truest sense. He is a homebound pilgrim, nostalgic about his past. His relentless search for roots earned for him Sahitya Academy Award for "Relationship" in 1981.
\end{abstract}

Keywords: culture, Identity, Indian English Poetry, Jayanta Mahapatra, Post-colonial

\section{Introduction}

Jayanta Mahapatra has uplifted Indian English poetry to a new height. He has dedicated his life to the service of poetry. Poetry provides him the sustenance to live in this dark, gloomy world. Through his poetry, he emerges as a perfect postcolonial poet trying to create his identity. Poetry enlightens his world and broadens his vision. In "Lines of My Poem", he specifies and concretizes the position of poetry in his life:

Poem, my mother, how

Pain has made you cross

the divide between past and future.

You are the cocoon

Of my broken soul.

$\mathrm{He}$ is an internationally acclaimed poet. "The Hindu"complements the poet thus:

His international reputation has been compared to that of Wordsworth...

Prof. K. Ayappa Paniker says of this Puri-bound poet

The sun of the eastern coast of India shines through his poems.

The poet identifies himself completely with his birthplace. In"Rain of Rites" he eulogises his mystic merging with his native land:

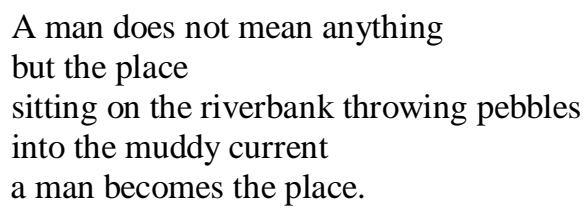

Mahapatra celebrates three layers of time - the mythical, the historical and the present. Orissan landscape, Puri,, Jagannath Temple, Konark, Dhauli, Orissan rituals, myths are the matters of sole importance in his poetry. He is a lover of solitude. He silently hovers in the past and the present. He tributes the Orissan tradition of martyrdom now and then. In Shadow Space, poem 11, he says:

To live here

antlered in sickness and disease

in the past of uncomprehended totems

and in the split blood of ancestors

one would wear like an amulet.

Jayanta Mahapatra's poetry is a continuous search for roots.

One can hear the chanting of the holy Jagannath temple in his poem" Main Temple Street" :

The temple points to unending rhythm.

Again, in "A Summer Poem", he imagines Puri to be the heart of India:

Over the soughing of the sombre wind

Priests chant louder than ever

The mouth of India opens.

"Myth" raises the question of identity. The image of the saffron-clad priest is the traditional symbol of purity and divinity. He belongs to the mythical land of Orissa. He is questioning the poet about his identity. Jayanta Mahapatra keeps the readers engaged in his unraveling of his identity. "Taste for Tomorrow" is highly significant. Puri, the land of the social underdogs is revealed in its all its aspects. The untouchable lepers and 
the sanctified priests are set in a binary. The image of 'crow' depicts unhealthy atmosphere of Puri. The poem opens thus: and the sanctified priests are set in a binary. The image of 'crow' depicts unhealthy atmosphere of Puri. The poem opens thus:

At Puri, the crows

the one wide street

lolls out like a giant's tongue.

Five faceless lepers move aside

as priests passes by.

The temple is presented in all its glory, beauty and majesty:

And at the streets end

The crowds thronging the temple door :

a huge holy flower

swaying in the wind of greater reasons.

The poet always whirls back to his past . In poem "Afternoon", he articulates:

The past

lies everywhere like water.

Cultural, familial and historical past always remain the sole haven to the poet. Memory is all important to him. Past remains his peace, bliss and happiness. His father, mother, grandfather, Orissan myths, folklores always allure him . He is afraid of the present . He always tries to avoid it whole- heartedly to float among the mythical past . The typical devoted Oriya family and their beliefs are portrayed in "Consolation" where the poet loses himself amidst the memory of his dying father:

My father, teetoteller, vegetarian

took two baths a day,

one at dawn , the other

before his evening obeisance

to Lord Shiva at the temple. [ "A Whiteness of Bone"]

The image of his mother pressing sugar against his wounds to stop bleeding is an unfading memory to him. In "Orissan Landscape", the poet's mother becomes the symbol of universal motherhood who always tries to protect her son from all the hazards of life . In "Waiting " poem no. 27 , he firmly upholds his identity on the bosom of Orissa :

This is the town where I was born : here with others

Year after year I celebrate the joyous festival.

The poet fondly cherishes his childhood memories in "A Whiteness of Bone" :

The old brickwalLs of my house

go down into shadow.

The glory of his Orissan ancestors is vividly recalled in "Dhauligiri". Mahapatra remembers the great Kalinga War of 260 B.C. in Orissa after which the great King Ashoka was converted to Buddhism. The conversion of the poet is not the focus of the poem. The poet here celebrates the glory of his ancestors who though failed tried their best to defend their freedom. The river Daya which was the witness of this great war is itself is a mythical space to the poet. The poet gets nostalgic about the historical past of the Konark temple. The 12 year old boy who fixed the crowning stone of the Sun temple and then sacrificed his life to save his father's honour is always present in the poet's mind. The poet identifies himself with the boy:

And inside me

is the boy

I found

Tracked by stone.

Jayanta Mahapatra is the child of the Sun and the sea of Puri. In "Dawn at Puri", "Sunburse","The Exile", "The Beggar Takes it as Solace" the local landscape is faithfully created. In "The Abandoned British Cemetary of Balasore", the poet becomes meditative:

This is history

I would not disturb it The ruins and marbles-

The crumbling wall of brick; the coma of alienated decay

How exactly should the archaic dead make me behave?

The poet gets wonder-struck at the beauty of Indian sculpture . He hovers in land of legends when he says:

Thirty nine graves, there legends

Floating in the twilight of baleful littoral 
The flaking history my intrusion does not inanimate..

Mahapatra adores Gandhi as the uncompromising and undeniable champion of truth. Though Gandhi is no more today he is always alive in the heart of the Indians. Today's India is tormented by violence, agitation, riots and insurgents. In this ever- darkening India it is high time that we should remember him and his invaluable ideas. In "Sometimes", the poet says :

Even the headless torso of Gandhi

In the city can speak

Like truth, unsaid most of the time

Yet almost said.["Bare Face"]

The poet deplores the fact that though India is free from the British yoke she is not free from the shackles of poverty. The suffering of his countrymen afflicts him very much. In “Freedom” his heart cries:

Here, old widows and dying men

Cherished their freedom

Bowing time after time In obstinate prayers

\section{Conclusion}

Jayanta Mahapatra unveils his past . The heroic Oriya past revives in his works in all its magnificence and grandeur. No mere Oriya poet Mahapatra addresses the most major contemporary problems of India very faithfully. He transcends the personal to become universal, crosses the local to rise to the level of the national.

\section{References:}

[1]. "Studies in Indian Poetry in English" by Benoy Kumar Banerjee, Kaustav Bakshi, Debalina Bnerjee [published by Books Way, Second Revised Edition, 2012]

[2]. "Recollection as Redemption" by Nandini Sahoo [Authors Press]

[3]. "Twelve Modern Indian Poets" by Arvind Krishna Meherotra [published by Oxford University Press] 